DANIJELA N. VASILIJEVIĆ ${ }^{1}$

UNIVERSITY IN KRAGUJEVAC

FACULTY OF PEDAGOGY, UŽICE (SERBIA)

MARINA Ž. SEMIZ ${ }^{2}$

UNIVERSITY IN KRAGUJEVAC

FACULTY OF PEDAGOGY, UŽICE (SERBIA)

BRANKA M. ADŽIĆ ${ }^{3}$

PRIMARY SCHOOL „NADA MATIĆ“, UŽICE (SERBIA)

\title{
NATIONAL IDENTITY IN THE TEXTBOOKS OF ENGLISH AS A FOREIGN LANGUAGE
}

ABSTRACT. Starting from the argument that foreign language teaching represents a suitable context for introducing national symbols of different countries, but also the learners' own country, the role of textbooks of English as a foreign language in development and empowering the national identity of students in lower primary school was examined. With regards to different conceptualisations the national identity was operationalised in 11 categories: religion, customs and tradition, national feelings, language, symbols and features, solidarity and togetherness, cultural heritage, important people, geography terms, family and general information. The research was performed through the method of theoretic analysis and the method of content analysis. The units of analysis are: a) sentences of basic text in textbooks, b) sentences of additional information content, and c) image content. The research included English language textbooks for lower prima-

\footnotetext{
vasilijevic@pfu.kg.ac.rs

semizmarina@pfu.kg.ac.rs

branka.adzic@osnadamatic.edu.rs1972
}

The paper was created within the project Teaching and Learning: Issues, Goals and Perspectives, number 179026, supported by the Ministry of Education, Science and Technological Development of the Republic of Serbia.

This paper was submitted on May $10^{\text {th }}, 2021$ and accepted for publication at the meeting of the Editorial Board held on November 16 ${ }^{\text {th }}, 2011$. 
ry school licensed in the Republic of Serbia $(\mathrm{N}=12)$. Research results indicated that textbooks generally do not contribute to forming and empowering of national identity of students in lower primary school, especially with regards to categories: national feelings, historic subjects, language, family, solidarity, and togetherness.

KEYWORDS: national identity; English language textbooks; global identity; content analysis; students of lower primary school.

INTRODUCTION

Due to the significance that is attributed to pedagogy, education, and educational systems in the formation of the national identity, in promotion and nurturing national values, goals and norms of behavior, significant number of foreign theoretic discussions and studies is dedicated to examination of the influence of educational content on national identity of children and students (Barrett, 2005; Barrett \& Davis, 2008; Köroğlu \& Elban, 2020; Philippou \& Klerides, 2010; Pöllmann, 2008; Rapoport, 2009; Tartakovsky, 2011). However, studying national identity in pre-school and school age is an overlooked researched field of domestic researchers, especially pedagogists and the creators of educational policy.

National identity is usually defined as a collection of notions and emotions that reflect the relation of an individual towards the nation (Barrett \& Davis, 2008), as a part of social identity that reflects self-notion and self-distinction of an individual as a part of a certain national group characterized by joint historic and cultural background, values and beliefs (Brubaker, 1994). It is defined as a perceived congruence of the concept of self-identity and the concept of nation (Hodgins et al., 2015). Whether treated as a subjective or social, i.e. collective construction, national identity includes the following distinctive components: a) subjective belief of an individual to belong to a certain nation; $b$ ) the sense of national belonging; c) attitudes and emotions toward the nation; d) stereotypes on typical characteristics and features of people who belong to their own national group and other national groups; d) experience of inclusion and self-perseption as similar to other members of the national group; and e) the willingness and readiness of an individual to internationalise the national culture, values and behavior norms (Barrett, 2005; Phinney, 1990). 
In order to comprehend the specificity and complexity of national identity in the context of education, the fact that it is a social and politically constructed phenomenon must be considered. Being one of multiple identities obtained by an individual due to the involvement in a national group and identification with it, its specificity is reflected in it as an instrument of political and ideological indoctrination.

According to the plurality of meaning in which the concept of national identity is used, the starting theoretic hypothesis of this paper is that forming and building national identity denotes the life process, which is built and reconstructed continuously through the interactions and engagement of individuals in social, cultural and educational practice and institutions. The development and empowerment of national identity is influenced by numerous factors: programme framework and teaching content, teachers with formed social and political attitudes, values and ideologies, various pedagogical beliefs and approaches etc. (Hand \& Pearce, 2009, 2011; Sant \& Hanley, 2018).

Deriving from the thesis that foreign language teaching is recognized as a suitable context for introducing national symbols of different countries, but also the learners' own country and identity (Köroğlu \& Elban, 2020; McVeigh, 2004; Priyanti, 2019; Turnbull, 2017), in this paper, the analyses of the textbooks used in teaching English as a foreign language in lower primary schools in Serbia from the perspective of their contribution to development and empowerment of national identity was conducted, from the theoretic and empiric aspect. Language teaching includes introducing and learning various cultural values in certain sociolinguistic, cultural, and ideological dimensions, and by its nature, textbooks in foreign languages are ideologically conceived due to their promotion of dominant culture and values (Wang, 2016).

Numerous authors advocate the thesis that learning English as a global language would promote students' global identity, contribute to development of intercultural awareness, i.e., development of awareness on the existence of the global community that exceed national borders, but does not deny the significance of states nor nations (Köroğlu \& Elban, 2020). Furthermore, certain authors point out great possibilities in English language teaching for developing national identity and accepting universal values. Opposing attitudes are also present on increasing English language hegemo- 
ny and on the negative influence on national identity of individuals from non-English-speaking area (McVeigh, 2004).

The questions on the relations between teachers' political perception on nation and national identity and their pedagogic decisions and approaches in practice came in the focus of consideration. (Sant \& Hanley, 2018). Generally, four different pedagogical approaches in national identity education within discourse on civic nationalism: avoiding, promotion, rejection, and problematisation (Hand \& Pearce, 2009, 2011). Within the first approach, teachers tend to avoid certain subjects on national identities guiding discussions and work with students to a safer territory. Another pedagogic approach means active promotion of national identities. In the third pedagogic option teachers reject promotion of messages and values incorporated in the national identities. In the fourth pedagogic approach, problematization, teachers present national identity as an open or controversial point and invite students to discuss about it.

\section{RESEARCH ON FOREIGN LANGUAGE TEXTBOOKS AND NATIONAL IDENTITY}

In a qualitative study Köroğlu and Elban (2020) researched to what extent textual and visual elements of English language textbooks in state high schools in Turkey promote national and global identity. The data showed that the analyzed high school textbooks, except in the $10^{\text {th }}$ grade, include more elements of global identity than elements of national identity. In accordance with studying English as a global language the study results show that textbooks in foreign language teaching teach students in global identity, but have significantly less influence in national identity development and promotion. It was determined that the most prominent elements of national identity in the analyzed English language textbooks include the notion of national history, national symbols, institutions, and structures, while global identity is dominantly promoted through universal values and intercultural interaction.

Priyanti (2019) conducted a qualitative analysis of the most represented and widely accepted textbook of English as a foreign language (EFL - English as a Foreign Language) in state schools in Indonesia from a standing point of its contribution to students' 
identity development. In the context of this study, the author highlighted that the choice and ways of presenting cultural and social values in the textbook influence the way students perceive their own cultural values with regards to projection of discursively represented values. For example, the textbook which was analyzed for the purpose of this study shows and promotes the community of English-speaking world, neoliberal work ethos as the key of financial and professional success of famous people and puts feminism and individualism as values. Other socio-cultural values, nations, races, artifacts or products outside English-speaking countries are rarely mentioned and almost always casually. Despite the received results, Priyanti (2019) considers foreign language learning and usage should not endanger own cultural identity and other social identities of individuals. On the contrary, learning English as a foreign language should enable students to know themselves better, to understand their own culture and other cultures, to adapt their own cultural identity and bring it closer to the new culture and language.

Numerous studies confirmed ideological background and nature of textbooks in foreign languages (Curdt-Christiansen \& Weninger, 2015; according to: Wang, 2016; Lee, 2009).

Through extensive review and analysis of foreign language textbooks it was determined that they are not a neutral tool in forming and transforming knowledge, but they always serve the interests of certain groups, forming students` understanding of social reality in a way that is proclaimed by a dominant, interest group (Curdt-Christiansen \& Weninger, 2015; according to: Wang, 2016).

The study conducted by Wang (2016) shows that textbooks of Chinese as a foreign language mostly include content and topics related to Chinese moral and civic education. Focusing on linguistic knowledge, cultural elements and ideology orientation, the content of the analyzed Chinese language textbook, is frequently irrelevant, or of no special interest to international students. In that way, education in Chinese language for international students is burdened with ideology and elements of Chinese national identity. The author suggests the use of open discourse in foreign language textbooks to enable greater participation of students in teaching practice and develop an intercultural understanding of cultural content within the curriculum.

Turnbull (2017) examined the perspective of Japanese students on positive and negative influence of education in English language 
on Japanese national and cultural identity. The findings suggest that one third of students consider the results of learning English as a foreign language in lowering Japanese national identity and weakening the feelings towards Japanese culture. Apart from the stated, the students identified Japanese language as a fundamental element of Japanese identity and expressed the wish for its continuous use in the context of studying English as a foreign language, despite the fact that it is conflicted with the guidelines of educational policy. The findings suggest the need to design English language teaching and learning as a support to Japanese identity.

The content analysis of textbooks of English as a foreign language in South Corea finds they positively promote western art and culture, while other, non-west cultures are consistently marginalized (Lee, 2009). The content of textbooks given in this study subtly and evidently glorifies western cultural groups, illustrates disregarding national and cultural groups that do not possess a lot of capital, do not enjoy a high rank in South Corea, which supports the argument that the observed dichotomy among societies and communities is founded upon capital, power, privileges, and unique manifestations of globalization, and not the geographical location.

\section{METHODOLOGY}

Upon the knowledge on the importance that foreign language textbooks can have on the cognition of global community and global identity, but also on self condition and national identity, a general research goal was defined: examine to what extent textbooks of English as a foreign language contribute in forming and empowering national identity with students of lower primary school. The aim of the research is operationalised through two scientific-research tasks: 1) establish the content share on national identity in English language textbooks for the first, second, third and fourth grade of primary school; 2) examine the representation and the ability to develop various categories of national identity in English language textbooks for lower primary school.

The independent variable is represented by basic textual, additional informational and visual content of the analyzed textbooks, while dependent variable is national identity, i.e. the categories of national identity (religion, custom and tradition, national feeling, language, symbols and characteristics, solidarity and togetherness, cultural 
heritage, important people, national geographic concepts, family and the category general information). The research is based upon the implementation of methods of theoretic analysis and content analysis. The units of analysis are: a) sentences of basic text, b) statements, i.e., sentences of additional information material and c) visual (pictorial) elements of content in a textbook; All units under analysis are separately classified in the belonging categories of national identity.

The research sample is random and is consisted of 12 English language textbooks licensed in the Republic of Serbia for the academic year 2020/21, three publishing houses for the first four grades of primary school (Data Status - Smart Junior 1-4, Klett - Playway to English 1-4, Freska - Smiles 1-4).

\section{RESULTS AND DISCUSSION}

\section{THE SHARE OF NATIONAL CONTENT IN ENGLISH LANGUAGE TEXTBOOKS FOR THE} FIRST, SECOND, THIRD AND FOURTH GRADE OF PRIMARY SCHOOL

As suggested in Table 1 there is almost no evidence of the share of national content in English language textbooks for the first grade of primary school. The textbooks being exclusively pictorial, the identification of categories of national identity was possible only in the visual media domain. However, pictorial national identification is present in only two examples of one publisher. One picture in the category customs and traditions and symbols and characteristics makes the share of $0.20 \%$ of total textbook content of one publisher. Namely, within the topic Food, two integrated pictures are showntraditional food in Serbia and the flag of the Republic of Serbia which is exclusively in purpose of national identification.

In the second grade, also, (Table 2) elements of national identity were not found in the basic content, while only one publishing house in additional information domain included content regarding Serbian national identity in categories general information, customs and traditions, cultural heritage, and persons. Their total share within additional information content is $12.94 \%$ and is in the textbook of this publisher in the range from $1.17 \%$ to $8.23 \%$.

General information refers mostly to personal names typical for Serbian region and the name of the Republic of Serbia; cultural heritage is recognized on one example of Children Museum; and impor- 
tant people, also an example of a female athlete from Serbia. The example is classified in the category customs and tradition and was marked as false. Namely, the claim that Mother`s Day is celebrated in Serbia is false. According to the accompanying text, the assumption is that it was meant to be Women's Day. Mother's Day is a national holiday in the USA celebrated on $9^{\text {th }}$ May, while Women's Day is an international holiday celebrated on $8^{\text {th }}$ March and is dedicated to all women.

Visual national content representation is in the range from $0 \%$ to 2.13\% (Table 3). The most recorded units are in the category of symbols and characteristic (Serbian flag), followed by category customs and tradition (national dish, national costume). Cultural heritage is represented by a photo of Children`s Museum, important people with a photography of a female athlete, and geographic concept through the map of Europe, Asia and Africa with the Republic of Serbia marked on the map. The pictures are in the purpose of clarification to the information parts of the textbook.

Likewise, in the third grade (Table 4), national content is not incorporated in the basic part of the text. Only in the additional information material some elements of national identity can be recognized, therewith a dichotomy was observed in the representation of the evidenced categories, except from the category general information which is present in the textbooks of two publishers. Visual content mostly accompanies the evidenced descriptions in additional information material.

General information are related to introduction (national names, the name of the country, capital, address, dialing codes, city transportation); within the category customs and traditions one, however, false example of traditional Serbian costume was recorded-red shoes do not complement the shown and described national costume from Šumadija. In the textbook published by Freska there is a visual representation of a sportswoman Ivana Španović (famous people) and national toponyms, mountain Avala, the city of Belgrade are just noted in text.

Textbooks for the fourth grade of primary school are slightly different with regards to the representation of elements of national identity in the basic content by only one publisher (Table 5). The most units under analysis were registered in the general information category (personal name and surname, the name of the country, typical architecture), and significantly fewer in customs and tradition and religion (with the example of St. Sava, School Slava Celebration). 
The share of national content in the additional information material of the three publishers is in the range of $0 \%$ to $17.91 \%$. Most of the examples were found in the category general information (mostly repetition of the content from previous grades), however some examples were registered in categories geographic concepts (the Kalemegdan Park, Sava and Danube rivers, Silver Lake, Resava Cave, Guča), symbols and characteristics (Serbian flag, national currency), cultural heritage (the Kalemegdan fortress), famous people (singer Željko Joksimović) and customs and traditions (national costume, the Guča festival). The descriptions in the informative material are mostly accompanied by visual forms in categories symbols and characteristics, customs and tradition (national costume). The pictorial religious content (the The Temple of Saint Sava, slava bread and the icon of St. Sava) are recorded in a text titled St. Sava`s Day by only one publisher.

The visual content of national character is still unacceptably rarely represented in English language textbooks (from 0\% to $1.59 \%$ ). In fourth grade textbooks, viewed as a hole, slightly more identity categories were incorporated (religion, customs and tradition, symbols and tradition, cultural heritage and famous people) than in the textbooks for other three grades, however, there is no compliance in the representation of the mentioned categories with different publishers.

Viewed in general there can be no justification neither for the representation level, dispersion, continuity, nor the way of development of the notion of national identity in English language textbooks in lower primary school (Table 6). Accordingly, national identity as a multidimensional construct is not recognized. Low index of representation of national content can, in a qualitative sense, be questioned-false information, often repetition of identical content from grade to grade by the same publishers.

\section{THE REPRESENTATION AND WAY OF DEVELOPMENT OF DIFFERENT CATEGORIES OF NATIONAL IDENTITY IN ENGLISH LANGUAGE TEXTBOOKS FOR LOWER PRIMARY SCHOOL}

General opinion is that total participation of national identity content in English language textbooks in lower primary school is marginal, almost negligible (Table 6). In the basic text, no national identity categories were found in any of the analyzed textbooks, except for one publisher and in one text (one example) in the fourth-grade textbook. It was proved that categories national feel- 
ings, historic topics, language, solidarity and togetherness and family are not represented in textbooks whatsoever, either in additional information content or as pictorial material. Neither of the categories represented possesses any visible developmental line. Thus, for example, the category religion was recorded in only one fourth grade textbook and partially in the basic text and in part as pictorial within the topic Holidays-and that is celebrating School Slava Celebration, St. Sava;

Category customs and tradition is, in the basic text, identified only in the fourth grade and with only one publisher, where the tradition on celebrating school slava celebration is being explained. None of the Serbian customs is included in the textbook content. Visual forms referring to tradition are found in the textbooks for all four grades, but by only one publisher; they are mostly connected with traditional Serbian dishes and national costumes.

It is interesting that national symbols and characteristics are represented exclusively by a picture or description of a flag in additional information material, but not in the basic text; National anthem and coat of arms are not a subject of interest for textbook authors (adaptation); The description of the Serbian flag is found in the third and fourth grade, which is understandable due to students' age and the characteristics of the subject, however it should certainly be a compulsory content for all the publishers. Pictorial content is introduced from the first grade by only one publisher. The picture of the national flag is in the purpose of national identification, connected to the background, food, prominent athletes, and national costume.

General information is represented in additional information material from the second grade (in the third by only one publisher) are mainly connected to introduction (country of origin, city, address, personal names). False information is recorded, which was explained earlier. Pictorial content is related to wild animals (second grade) and means of transportation (third grade)-all by one publisher.

Category cultural heritage is present with the example of the Children's Museum in Belgrade (second grade, one publisher) and Kalemegdan fortress (fourth grade by the same publisher), both in description and in picture.

In the category famous people three examples in total were found with two publishers - two sportswomen and one singer of popular 
music; therefore, there are no famous people in science, art, culture.

When speaking on national geographic notions toponyms referring to the city of Belgrade are recorded (with two publishers), Kalemegdan Park, the Sava and Danube rivers (fourth grade, one publisher), Silver lake, Resava Cave (fourth grade, other publisher, all in one text), Avala mountain (third grade, one publisher), as well as geographic position of Serbia on the map of Europe and Asia (second grade with one publisher).

On the whole, it is evident that different publishers differently size the notion of national identity. It was shown that one publisher has no national identity content, whereas: a) Data Status gives examples within additional information content including general information, cultural heritage, personality, custom and tradition (second grade); general information (third grade) and general information and cultural heritage (fourth grade). Therefore, there are no examples considering religion, national feelings, historical topics, language, symbols and characteristics, solidarity and togetherness and family. Regarding the textbook as a visual media, no pictures of national significance were found in the first grade. Whereas, in the second grade, pictures of the flag were found (five), and one picture regarding general information of important people and national geographic notions. Illustrations of categories customs and traditions, symbols and characteristics, general information were recorded in the third grade, and in the fourth grade only the category symbols and characteristics. Pictorial content is mainly referred to additional information, therefore it is understandable to have similar division of the noted categories of national identity, except for the category symbols and characteristics; b) only in the third and fourth grade textbooks of Freska publisher the categories of national identity were observed in the domain of additional information: general information (five), important people (four) and geographic term (two) are found in the third grade; and general information (four), geographic term (four), customs and tradition (one) in the fourth grade of primary school. National pictorial content of the first and second grade are related to customs and tradition, symbols and characteristics. In the third grade the category people is introduced (one example), and in the fourth religion (two). This publisher is special in the way that it is the only one which explains the school slava celebration in Serbia in the basic textbook content, which comprises the categories customs and tra- 
dition, religion, and also the category general information (Serbian names, surnames, architecture).

CONCLUSION The research findings indicate that, as a whole, English language textbook for lower primary school are not adapted to the region they are intended, since there is minor representation of the national significant content, i.e. there are textbooks which content concept absolutely does not comprise the national identity of the textbook consumers, therefore one cannot advocate the developmental categories of national identity. Moreover, wrong information was registered considering Serbian national characteristics. Thus, only global identity is being nurtured, which was pointed out in the previous research (Lee, 2009; Priyanti, 2019). The obtained results are in favor of the idea that English language textbooks promote universal values, like mutual respect, understanding, empathy, and openness towards diversity (Köroğlu \& Elban, 2020), in order to significantly support the development of students ' national identity.

It is obvious that different publishers differently handle the national identity categories, and that authors' copyright allow the possibility of incorporating content of national significance in all the thematic parts. There can be a more dimensional representation of national identity categories. E.g., while talking about art it is possible to name eminent Serbian painters, occupations such as Serbian scientists, artists, athletes; the context People from different parts of the world should incorporate Serbia and its customs and traditions, and family holidays should include family holidays in Serbia.

The personalization of English language content is in question in almost all the categories of national identity, except for the category of general information and geographic terms. Lower primary school students will not be able to clarify their religious identity, family customs and traditions, specific national script (Cyrillic), national feelings, name the national anthem, coat of arms, list the most important events in history, point to the importance of solidarity and togetherness and clarify the importance of cultural heritage and important people for Serbian national identity.

In our opinion, it is necessary to actualize the issue of national identity in textbooks for lower primary school, to standardize the dimension of the content of national significance (scope, depth, continuity, and dynamics) in the curricula, in lower, as well as in 
higher primary school. The performed textbook analysis showed that the examined components of national identity are insignificantly present, which can equally be attributed to the programme framework, hidden curriculum and educational policies within which the analyzed textbooks were created and approved for the use in lower grades of primary school.

In the focus of the analyses were the sentences of the basic text and additional informational content of the textbooks, as well as the visual content, therefore it is difficult to provide the final answers and determine to what extent and how textbooks of English as a foreign language influence identity development of students of lower primary school. Deriving from the assumption that textbook is not the only media to reproduce and re/construct national identity, the focus of further research should be aimed at examining of the use of textbooks in teaching practice, especially towards understanding the way teachers and students comprehend and understand national identity and the importance of educational content for development and nurturing one's own national identity. The curricula and textbooks are subject to teachers' decision and ability to interpret, thus the teachers' perception and teaching experience will probably influence the way the educational content that implies the terms of national identity, national connection, and identification is interpreted and presented to the students (Hand \& Pearce, 2009, 2011; Pöllmann, 2008). The obtained results, further suggest the necessity of development of critical thinking on the issues of national identity with all the participants in education system, but especially with the direct participants in education and pedagogy.

REFERENCES: Barrett, M. (2005). National Identities in Children and Young people. In: S. Ding, K. Littleton (eds.) Children's Personal and Social Development (181-220). Milton Keynes: The Open University/Blackwell.

Barrett, M, Davis, S. C. (2008). Applying Social Identity and Self-Categorization Theories to Children's Racial, Ethnic, National and State Identifications and Attitudes. In: S. M. Quintana, C. McKown (eds.) Handbook of Race, Racism and the Developing Child (72-110). Hoboken, NJ: Wiley.

Brubaker, R. (1994). Citizenship and Nationhood in France and Germany. Cambridge: Harvard University Press.

Curdt-Christiansen, X. L. (2008). Reading the World through Words: Cultural Themes in Heritage Chinese Language Textbooks. Language and Education, 22, 95-113. doi: $10.2167 / \mathrm{le} 721.0$ 
Hand, M, Pearce, J. (2009). Patriotism in British Schools: Principles, Practices and Press Hysteria. Educational Philosophy and Theory, 41 (4), 453-465.

Hand, M, Pearce, J. (2011). Patriotism in British Schools: Teachers' and Students' Perspectives, Educational Studies, 37 (4), 405-418.

Hodgins J, Moloney, G, Winskel, H. (2015). The Importance of Australian National Identity to a Sense of Belonging of Anglo-Celtic and Chinese Cultural Groups in Regional Australia. National Identities, 18 (3), 345-68. doi: 10.1080/ 14608944.2015.1061490

Turnbull, B. (2017). Learner Perspectives on National Identity and EFL Education in Japan: Report of a Questionnaire Study. The Journal of Asia TEFL, 14 (2), 211--227.

Köroğlu, Z. Ç, Elban, M. (2020). National and Global Identity Perspectives of Textbooks: Towards a Sense of Global Identity. Advances in Language and Literary Studies, 11 (5), 55-65.

Lee, I. (2009). Situated Globalization and Racism: An Analysis of Korean High School EFL Textbooks. Language and Literacy, 11, 1-14.

McVeigh, B. J. (2004). Foreign Language Instruction in Japanese Higher Education: The Humanistic Vision or Nationalist Utilitarianism? Arts and Humanities in Higher Education, 3 (2), 211-227. doi:10.1177/1474022204042687

Philippou, S, Klerides, E. (2010). On Continuity and Change in National Identity Construction: An Initial Note on Greek-Cypriot Education, 19602010. The Cyprus Review, 22 (2), 219-233.

Pöllmann, A. (2008). National Attachment among Berlin and London Head Teachers: The Explanatory Impact of National Identity, National Pride and Supranational Attachment. Educational Studies, 34 (1), 45-53. doi: 10.1080/ 03055690701785277

Phinney, J. S. (1990). Ethnic Identity in Adolescents and Adults: Review of Research. Psychological Bulletin, 108 (3), 499-514. Available at https:// doi.org/10.1037/0033-2909.108.3.499

Priyanti, N. (2019). The Effects of an EFL Textbook on Learners' Identity Construction. Polyglot: Jurnal Ilmiah, 15(2), 187-202. doi:10.19166/ pji.v15i2.1661

Rapoport, A. (2009). Patriotic Education in Russia: Stylistic Move or a Sign of Substantive Counter-Reform? Educational Forum, 73 (2), 141-152.

Sant, E, Hanley, C. (2018). Political Assumptions Underlying Pedagogies of National Education: The Case of Student Teachers Teaching 'British Values' in England. British Educational Research Journal, 44 (2), 319-337.

Tartakovsky, E. (2011). National Identity of High-School Adolescents in an Era of Socio Economic Change: Russia and Ukraine in the Post-Perestroika Period. Journal of Youth Adolescence, 40, 231-244. doi: 10.1007/ s10964-010-9509-6 
Turnbull, B. (2017). Learner Perspectives on National Identity and EFL Education in Japan: Report of a Questionnaire Study. The Journal of Asia TEFL, 14 (2), 211-227.

Wang, D. (2016). Learning or Becoming: Ideology and National Identity in Textbooks for International Learners of Chinese. Cogent Eduacation, 3 (1), doi: $10.1080 / 2331186 \mathrm{X} .2016 .1140361$

\section{APPENDIX}

\begin{tabular}{|c|r|r|r|r|}
\hline $\begin{array}{c}\text { THE RECORDED } \\
\text { CATEGORIES OF NATIONAL } \\
\text { IDENTITY/PUBLISHERS }\end{array}$ & $\begin{array}{c}\text { CUSTOMS AND } \\
\text { TRADITION } \\
\text { (F AND \%) }\end{array}$ & $\begin{array}{c}\text { SYMBOLS AND } \\
\text { CHARACTERISTI } \\
\text { CS } \\
\text { (F AND \%) }\end{array}$ & $\begin{array}{c}\text { OTHER } \\
\text { CATEGORIES } \\
\text { (F AND \%) }\end{array}$ & $\begin{array}{c}\text { TOTAL SHARE OF } \\
\text { VISUAL CONTENT } \\
\text { OF NATIONAL } \\
\text { SIGNIFICANCE } \\
\text { (F AND \%) }\end{array}$ \\
\hline Freska & 1 & 1 & 0 & $0,20 \%$ \\
N=337 & $0,10 \%$ & $0,10 \%$ & $0 \%$ & $0,20 \%$ \\
\hline \hline
\end{tabular}

TABLE 1: THE SHARE OF VISUAL NATIONAL CONTENT IN ENGLISH LANGUAGE TEXTBOOKS OF THE FIRST GRADE OF PRIMARY SCHOOL

\begin{tabular}{|l|r|r|r|r|r|r||}
\hline \multicolumn{1}{|c|}{$\begin{array}{c}\text { THE RECORDED } \\
\text { CATEGORIES OF } \\
\text { NATIONAL IDENTITY/ } \\
\text { PUBLISHERS }\end{array}$} & $\begin{array}{c}\mathrm{CT} \\
\text { (F AND \%) }\end{array}$ & $\begin{array}{c}\text { GI } \\
\text { (F AND \%) }\end{array}$ & $\begin{array}{c}\mathrm{CH} \\
\text { (F AND \%) }\end{array}$ & $\begin{array}{c}\text { P } \\
\text { (F AND \%) }\end{array}$ & $\begin{array}{c}\text { OC } \\
\text { (F AND \%) }\end{array}$ & $\begin{array}{c}\text { TSNC } \\
\text { (F AND \%) }\end{array}$ \\
\hline $\begin{array}{l}\text { Data Status } \\
\text { N=85 }\end{array}$ & 1 & 7 & 2 & 1 & 0 & 11 \\
\hline Klett & $0,17 \%$ & $8,23 \%$ & $2,35 \%$ & $0,17 \%$ & $0 \%$ & $12,94 \%$ \\
N=0 & 0 & 0 & 0 & 0 & 0 & 0 \\
\hline Freska & 0 & $0 \%$ & $0 \%$ & $0 \%$ & $0 \%$ & $0 \%$ \\
N=0 & $0 \%$ & 0 & 0 & 0 & 0 & 0 \\
\hline \hline
\end{tabular}

TABLE 2: THE SHARE OF NATIONAL CONTENT IN ENGLISH LANGUAGE TEXTBOOKS OF THE SECOND GRADE OF REGARDING ADDITIONAL INFORMATION

Key: CT - customs and tradition, SC - symbols and characteristics; GI general information, $\mathrm{CH}$ - cultural heritage; $\mathrm{P}$ - people; GT - geographic terms; OC - other categories, TSVC - total share of national content regarding additional information 


\begin{tabular}{|c|c|c|c|c|c|c|c|c|}
\hline $\begin{array}{c}\text { THE RECORDED } \\
\text { CATEGORIES OF } \\
\text { NATIONAL IDENTITY/ } \\
\text { PUBLISHERS }\end{array}$ & $\begin{array}{l}\text { CT } \\
(\text { F AND } \\
\%)\end{array}$ & \begin{tabular}{c|}
$\mathrm{SC}$ \\
$(\mathrm{F} \mathrm{AND}$ \\
$\%)$
\end{tabular} & $\begin{array}{c}\text { Gl } \\
\text { (F AND \%) }\end{array}$ & $\begin{array}{c}\mathrm{CH} \\
(\mathrm{F} \mathrm{AND} \\
\%)\end{array}$ & $\begin{array}{l}\mathrm{P} \\
(\mathrm{F} \text { AND } \\
\%)\end{array}$ & $\begin{array}{l}\text { GT } \\
(\text { F AND } \\
\%)\end{array}$ & $\begin{array}{c}\text { OC } \\
(\mathrm{F} \mathrm{AND} \\
\%)\end{array}$ & $\begin{array}{c}\text { TSNC } \\
(\mathrm{F} \mathrm{AND} \\
\%)\end{array}$ \\
\hline Data Status & 0 & 5 & 1 & 1 & 1 & 1 & 0 & 5 \\
\hline $\mathrm{N}=422$ & $0 \%$ & $1,18 \%$ & $0,23 \%$ & $0,23 \%$ & $0,23 \%$ & $0,23 \%$ & $0 \%$ & $2,13 \%$ \\
\hline Klett & 0 & 0 & 0 & 0 & 0 & 0 & 0 & 0 \\
\hline $\mathrm{N}=433$ & $0 \%$ & $0 \%$ & $0 \%$ & $0 \%$ & $0 \%$ & $0 \%$ & $0 \%$ & $0 \%$ \\
\hline Fresca & 2 & 2 & 0 & 0 & 0 & 0 & 0 & 4 \\
\hline $\mathrm{N}=412$ & $0,48 \%$ & $0,48 \%$ & $0 \%$ & $0 \%$ & $0 \%$ & $0 \%$ & $0 \%$ & $0,97 \%$ \\
\hline
\end{tabular}

TABLE 3: THE SHARE OF VISUAL NATIONAL CONTENT IN ENGLISH LANGUAGE TEXTBOOKS OF THE SECOND GRADE OF PRIMARY SCHOOL

Key: CT - customs and tradition, SC - symbols and characteristics; GI general information, $\mathrm{CH}$ - cultural heritage; $\mathrm{P}$ - people; GT - geographic terms; OC - other categories, TSVC - total share of national content

\begin{tabular}{|c|c|c|c|c|c|c|c|c|}
\hline \begin{tabular}{|c|} 
THE RECORDED \\
CATEGORIES OF \\
NATIONAL IDENTITY/ \\
PUBLISHERS
\end{tabular} & $\begin{array}{c}\text { CT } \\
(\mathrm{F} \mathrm{AND} \\
\%)\end{array}$ & $\begin{array}{c}\text { SC } \\
(\text { F AND } \\
\%)\end{array}$ & $\begin{array}{c}\text { Gl } \\
(\text { F AND \%) }\end{array}$ & $\begin{array}{c}\mathrm{CH} \\
(\mathrm{F} \text { AND } \\
\%)\end{array}$ & $\begin{array}{c}\mathrm{P} \\
(\mathrm{F} \mathrm{AND} \\
\%)\end{array}$ & $\begin{array}{l}\text { GT } \\
(\text { F AND } \\
\%)\end{array}$ & $\begin{array}{c}\text { OC } \\
(\mathrm{F} \mathrm{AND} \\
\%)\end{array}$ & $\begin{array}{c}\text { TSNC } \\
(\mathrm{F} \mathrm{AND} \\
\%)\end{array}$ \\
\hline a) Data Status & 3 & 1 & 7 & 0 & 0 & 0 & 0 & 11 \\
\hline $\mathrm{N}=115$ & $2,60 \%$ & $1,86 \%$ & $6,08 \%$ & $0 \%$ & $0 \%$ & $0 \%$ & $0 \%$ & $9,57 \%$ \\
\hline a) Klett & 0 & 0 & 0 & 0 & 0 & 0 & 0 & 0 \\
\hline $\mathrm{N}=0$ & $0 \%$ & $0 \%$ & $0 \%$ & $0 \%$ & $0 \%$ & $0 \%$ & $0 \%$ & $0 \%$ \\
\hline a) Freska & 0 & 0 & 5 & 0 & 4 & 2 & 0 & 11 \\
\hline $\mathrm{N}=104$ & $0 \%$ & $0 \%$ & $4,80 \%$ & $0 \%$ & $3,84 \%$ & $1,92 \%$ & $0 \%$ & $10,58 \%$ \\
\hline b) Data Status & 2 & 2 & 2 & 0 & 0 & 0 & 0 & 6 \\
\hline $\mathrm{N}=558$ & $0,35 \%$ & $0,35 \%$ & $0,35 \%$ & $0 \%$ & $0 \%$ & $0 \%$ & $0 \%$ & $1,08 \%$ \\
\hline b) Klett & 0 & 0 & 0 & 0 & 0 & 0 & 0 & 0 \\
\hline $\mathrm{N}=454$ & $0 \%$ & $0 \%$ & $0 \%$ & $0 \%$ & $0 \%$ & $0 \%$ & $0 \%$ & $0 \%$ \\
\hline b) Freska & 0 & 3 & 0 & 0 & 1 & 0 & 0 & 4 \\
\hline $\mathrm{N}=409$ & $0 \%$ & $0,73 \%$ & $0 \%$ & $0 \%$ & $0,24 \%$ & $0 \%$ & $0 \%$ & $0,98 \%$ \\
\hline
\end{tabular}

TABLE 4: THE SHARE OF NATIONAL CONTENT IN ENGLISH LANGUAGE TEXTBOOKS OF THE THIRD GRADE OF PRIMARY SCHOOL REGARDING: A) ADDITIONAL INFORMATION AND B) VISUAL CONTENT

Key: CT - customs and tradition, SC - symbols and characteristics; GI general information, $\mathrm{CH}$ - cultural heritage; $\mathrm{P}$ - people; $\mathrm{GT}$ - geographic terms; OC - other categories, TSVC - total share of national content 


\begin{tabular}{|c|c|c|c|c|c|c|c|c|c|}
\hline $\begin{array}{c}\text { THE RECORDED } \\
\text { CATEGORIES OF } \\
\text { NATIONAL } \\
\text { IDENTITY/ } \\
\text { PUBLISHERS }\end{array}$ & $\begin{array}{c}\mathrm{R} \\
(\mathrm{F} \text { И } \\
\%)\end{array}$ & $\begin{array}{c}\text { CT } \\
\left(\begin{array}{c}\text { F AND } \\
\%)\end{array}\right.\end{array}$ & $\begin{array}{c}\text { SC } \\
\left(\begin{array}{c}\text { F AND } \\
\%)\end{array}\right.\end{array}$ & $\begin{array}{c}\text { Gl } \\
(\text { F AND } \\
\%)\end{array}$ & $\begin{array}{c}\mathrm{CH} \\
(\mathrm{F} \text { AND } \\
\%)\end{array}$ & $\begin{array}{c}\mathrm{P} \\
\text { (F AND } \\
\%)\end{array}$ & $\begin{array}{c}\text { GT } \\
\text { (F AND } \\
\%)\end{array}$ & $\begin{array}{c}\text { OC } \\
(\text { F AND } \\
\%)\end{array}$ & $\begin{array}{c}\text { TSNC } \\
\text { (F AND } \\
\%)\end{array}$ \\
\hline $\begin{array}{l}\text { a) Data Status } \\
\mathrm{N}=546\end{array}$ & $\begin{array}{r}0 \\
0 \%\end{array}$ & $\begin{array}{r}0 \\
0 \%\end{array}$ & $\begin{array}{r}0 \\
0 \%\end{array}$ & $\begin{array}{r}0 \\
0 \%\end{array}$ & $\begin{array}{r}0 \\
0 \%\end{array}$ & $\begin{array}{r}0 \\
0 \%\end{array}$ & $\begin{array}{r}0 \\
0 \%\end{array}$ & $\begin{array}{r}0 \\
0 \%\end{array}$ & $\begin{array}{r}0 \\
0 \%\end{array}$ \\
\hline $\begin{array}{l}\text { a) Klett } \\
N=589\end{array}$ & $\begin{array}{r}0 \\
0 \%\end{array}$ & $\begin{array}{r}0 \\
0 \%\end{array}$ & $\begin{array}{r}0 \\
0 \%\end{array}$ & $\begin{array}{r}0 \\
0 \%\end{array}$ & $\begin{array}{r}0 \\
0 \%\end{array}$ & $\begin{array}{r}0 \\
0 \%\end{array}$ & $\begin{array}{r}0 \\
0 \%\end{array}$ & $\begin{array}{r}0 \\
0 \%\end{array}$ & $\begin{array}{r}0 \\
0 \%\end{array}$ \\
\hline $\begin{array}{l}\text { a) Freska } \\
N=442\end{array}$ & $\begin{array}{r}1 \\
0,22 \%\end{array}$ & $\begin{array}{r}2 \\
0,45 \%\end{array}$ & $\begin{array}{r}0 \\
0 \%\end{array}$ & $\begin{array}{r}7 \\
1,58 \%\end{array}$ & $\begin{array}{r}0 \\
0 \%\end{array}$ & $\begin{array}{r}0 \\
0 \%\end{array}$ & $\begin{array}{r}0 \\
0 \%\end{array}$ & $\begin{array}{r}0 \\
0 \%\end{array}$ & $\begin{array}{r}10 \\
14,93 \%\end{array}$ \\
\hline $\begin{array}{l}\text { b) Data Status } \\
N=113\end{array}$ & $\begin{array}{r}0 \\
0 \%\end{array}$ & $\begin{array}{r}1 \\
0,88 \%\end{array}$ & $\begin{array}{r}0 \\
0 \%\end{array}$ & $\begin{array}{r}10 \\
8,84 \%\end{array}$ & $\begin{array}{r}2 \\
1,76 \%\end{array}$ & $\begin{array}{r}2 \\
1,76 \%\end{array}$ & $\begin{array}{r}2 \\
1,76 \%\end{array}$ & $\begin{array}{r}0 \\
0 \%\end{array}$ & $\begin{array}{r}17 \\
15,04 \%\end{array}$ \\
\hline $\begin{array}{l}\text { b) Klett } \\
N=0\end{array}$ & $\begin{array}{r}0 \\
0 \%\end{array}$ & \begin{tabular}{r|}
0 \\
$0 \%$
\end{tabular} & $\begin{array}{r}0 \\
0 \%\end{array}$ & $\begin{array}{r}0 \\
0 \%\end{array}$ & $\begin{array}{r}0 \\
0 \%\end{array}$ & $\begin{array}{r}0 \\
0 \%\end{array}$ & $\begin{array}{r}0 \\
0 \%\end{array}$ & $\begin{array}{r}0 \\
0 \%\end{array}$ & \begin{tabular}{r|}
0 \\
$0 \%$
\end{tabular} \\
\hline $\begin{array}{l}\text { b) Freska } \\
N=67\end{array}$ & $\begin{array}{r}0 \\
0 \%\end{array}$ & $\begin{array}{r}1 \\
1,49 \%\end{array}$ & $\begin{array}{r}3 \\
4,47 \%\end{array}$ & $\begin{array}{r}4 \\
5,97 \%\end{array}$ & $\begin{array}{r}0 \\
0 \%\end{array}$ & $\begin{array}{r}0 \\
0 \%\end{array}$ & $\begin{array}{r}4 \\
5,97 \%\end{array}$ & $\begin{array}{r}0 \\
0 \%\end{array}$ & $\begin{array}{r}12 \\
17,91 \%\end{array}$ \\
\hline $\begin{array}{l}\text { c) Data Status } \\
\mathrm{N}=439\end{array}$ & $\begin{array}{r}0 \\
0 \%\end{array}$ & $\begin{array}{r}0 \\
0 \%\end{array}$ & $\begin{array}{r}3 \\
0,68 \%\end{array}$ & $\begin{array}{r}0 \\
0 \%\end{array}$ & $\begin{array}{r}2 \\
0,45 \%\end{array}$ & $\begin{array}{r}2 \\
0,45 \%\end{array}$ & $\begin{array}{r}0 \\
0 \%\end{array}$ & $\begin{array}{r}0 \\
0 \%\end{array}$ & $\begin{array}{r}7 \\
1,59 \%\end{array}$ \\
\hline $\begin{array}{l}\text { c) Klett } \\
\mathrm{N}=449\end{array}$ & $\begin{array}{r}0 \\
0 \%\end{array}$ & $\begin{array}{r}0 \\
0 \%\end{array}$ & $\begin{array}{r}0 \\
0 \%\end{array}$ & $\begin{array}{r}0 \\
0 \%\end{array}$ & $\begin{array}{r}0 \\
0 \%\end{array}$ & $\begin{array}{r}0 \\
0 \%\end{array}$ & $\begin{array}{r}0 \\
0 \%\end{array}$ & $\begin{array}{r}0 \\
0 \%\end{array}$ & $\begin{array}{r}0 \\
0 \%\end{array}$ \\
\hline $\begin{array}{l}\text { c) Freska } \\
N=437\end{array}$ & $\begin{array}{r}2 \\
0,45 \%\end{array}$ & $\begin{array}{r}2 \\
0,45 \%\end{array}$ & $\begin{array}{r}2 \\
0,45 \%\end{array}$ & $\begin{array}{r}0 \\
0 \%\end{array}$ & $\begin{array}{r}0 \\
0 \%\end{array}$ & $\begin{array}{r}0 \\
0 \%\end{array}$ & $\begin{array}{r}0 \\
0 \%\end{array}$ & $\begin{array}{r}0 \\
0 \%\end{array}$ & $\begin{array}{r}6 \\
1,37 \%\end{array}$ \\
\hline
\end{tabular}

TABLE 5: THE SHARE OF NATIONAL CONTENT IN ENGLISH LANGUAGE TEXTBOOKS OF THE FOURTH GRADE OF PRIMARY SCHOOL REGARDING: A) BASIC TEXT, B) ADDITIONAL INFORMATION AND C) VISUAL CONTENT

Key: $\mathrm{R}$ - religion, $\mathrm{CT}$ - customs and tradition, $\mathrm{SC}$ - symbols and characteristics; GI - general information, $\mathrm{CH}$ - cultural heritage; P - people; GT geographic terms; OC - other categories, TSVC - total share of national content

\begin{tabular}{|l|r|r|r|r|r|}
\hline $\begin{array}{c}\text { Publisher/ } \\
\text { Grade }\end{array}$ & FIRST GRADE & $\begin{array}{c}\text { SECOND } \\
\text { GRADE }\end{array}$ & THIRD GRADE & FOURTH GRADE & TOtAL \\
\hline Data Status & 0 & 20 & 17 & 24 & 63 \\
$\mathrm{~N}=3378$ & $0 \%$ & $2,12 \%$ & $1,47 \%$ & $2,18 \%$ & $1,86 \%$ \\
\hline
\end{tabular}

TABLE 6: TOTAL SHARE OF NATIONAL CONTENT WITH DIFFERENT PUBLISHER IN LOWER PRIMARY SCHOOL 
COLlection of PAPERS OF THE FACUlty OF Philosophy LI(3)/2021

\begin{tabular}{|l|r|r|r|r|r|}
\hline Klett & 0 & 0 & 0 & 0 & 0 \\
N=2830 & $0 \%$ & $0 \%$ & $0 \%$ & $0 \%$ & $0 \%$ \\
\hline Freska & 2 & 4 & 15 & 16 & 37 \\
$\mathrm{~N}=3199$ & $0,59 \%$ & $0,47 \%$ & $1,53 \%$ & $1,54 \%$ & $1,16 \%$ \\
\hline
\end{tabular}

TABLE 6: TOTAL SHARE OF NATIONAL CONTENT WITH DIFFERENT PUBLISHER IN LOWER PRIMARY SCHOOL

\section{ДАНИЈЕЛА Н. ВАСИЛИЈЕВИТ \\ УНИВЕРЗИТЕТ У КРАГУЈЕВЦУ \\ ПЕДАГОШКИ ФАКУЛТЕТ}

МАРИНА Ж. СЕМИЗ

УНИВЕРЗИТЕТ У КРАГУЈЕВЦУ

ПЕДАГОШКИ ФАКУЛТЕТ

БРАНКА М. АџИТ

ОШ „НАДА МАТИћ“, УЖИЦЕ (СРБИЈА)

НАЦИОНАЛНИ ИДЕНТИТЕТ У УЏБЕНИЦИМА

ЕНГЛЕСКОГ КАО СТРАНОГ ЈЕЗИКА

Полазећи од тезе да настава страног језика представља погодан контекст за упознавање националних обележја других држава, али и сопствене државе, разматрана је улога уџбеника енглеског као страног језика у развоју и снажењу националног идентитета ученика млађег школског узраста. У складу са различитим концептуализацијама, национални идентитет је операционализован у 11 категорија: религија, обичаји и традиција, национална осећања, језик, симболи и обележја, солидарност и заједништво, културна баштина, важне личности, географски појмови, породица и опште информације. У истраживању су примењене метода теоријске анализе и метода анализе садржаја. Јединице анализе су: а) реченице основног текста уџбеника; б) реченице додатног информативног садржаја; в) сликовни садржај. Истраживањем су обухваћени уџбеници енглеског језика млађих разреда основне школе лиценцираних у Републици Србији (N=12). Резултати истраживања су указали да уџбеници углавном не доприносе формирању и снажењу националног идентитета ученика млађег школског узраста, посебно у домену категорија: национална осећања, историјске теме, језик, породица, солидарност и заједништво. 
КљУчнЕ РЕчи: национални идентитет; уџбеници енглеског језика; глобални идентитет; анализа садржаја; ученици млађег школског узраста.

Овај чланак је објављен и дистрибуира се под лиценцом Creative Commons Ауторство-Некомерцијално Међународна 4.0 (CC BY-NC 4.0 |

https://creativecommons.org/licenses/by-nc/4.0/).

This paper is published and distributed under the terms and conditions of the Creative Commons Attribution-NonCommercial International 4.0 licence (CC BY-NC 4.0 | https://creativecommons.org/licenses/by-nc/4.0/). 